\title{
New polymorphisms and expression of the porcine ghrelin $(G H R L)$ gene in different pig breeds
}

\author{
K. Ropka-Molik ${ }^{1,5}$, M. Oczkowicz ${ }^{1}$, K. Piórkowska ${ }^{1}$, M. Różycki², \\ J. Romanek ${ }^{3}$ and M. Natonek-Wiśniewska ${ }^{4}$
}

\author{
National Research Institute of Animal Production, \\ ${ }^{1}$ Laboratory of Genomics, \\ ${ }^{2}$ Department of Genetics and Animal Breeding, \\ ${ }^{3}$ Department of Biotechnology of Animal Reproduction, \\ ${ }^{4}$ Department of Cytogenetics and Molecular Genetics of Animals \\ 32-083 Balice, Poland
}

(Received 16 May 2011; revised version 7 June 2011; accepted 18 June 2011)

\begin{abstract}
Growth and development traits are economically important in animal production, especially in pig breeding. Therefore, the porcine GHRL gene is considered as a candidate gene responsible for growth rate and body weight. The aim of our study was to identify new polymorphisms in the GHRL gene in pig. Ten novel single nucleotide polymorphisms (SNP's) were detected: four substitutions in exons, four in introns and two mutations in promoter region. We evaluated the GHRL mRNA abundance in porcine stomachs (fundus ventriculis) and ghrelin protein concentration in plasma in three breeds: Polish Landrace, Polish Large White and Pietrain. The results showed that transcript abundance of GHRL gene was significantly higher in Polish Landrace than in other two breeds $(\mathrm{P}<0.05)$. The mutation c. $-93 \mathrm{~A}>\mathrm{G}$ located in the promoter region affected expression of the GHRL gene. The AA genotype animals showed a significantly $(\mathrm{P}<0.05)$ higher expression level when compared to AG genotype animals.
\end{abstract}

KEY WORDS: pig, ghrelin, gene expression, SNP, polymorphism, GHRL

\section{INTRODUCTION}

Ghrelin is an appetite-stimulating hormone produced and secreted from the stomach (Kojima et al., 1999). This multifunctional peptide is involved in a

$\overline{{ }^{5} \text { Corresponding autor: e-mail: kropka@izoo.krakow.pl }}$ 
variety of biological functions including regulation of feeding behaviour (Chen et al., 2005), tissue growth and development (Leite-Moreira et al., 2007), hormone secretion and energy homeostasis (Kokkinos et al., 2007). Ghrelin was discovered in rat stomach and was regarded as the endogenous ligand specific for the growth hormone secretagogue receptor (GHS-R). Ghrelin stimulates GH release from primary pituitary cells via increasing intercellular calcium concentrations (Glavaski-Joksimovic et al., 2006).

The main role of this hormone is the regulation of feed intake, body weight, and gastrointestinal motility (Toshinai et al., 2006). In the mice, injection of ghrelin leads to increase of the feed intake, decrease energy expenditure and finally result in body weight gain (Nakazato et al., 2001). The stimulation of appetite by ghrelin involves complex hypothalamic action through stimulation of the orexigenic neuropeptide $\mathrm{Y}$, agouti-related protein and orexin-producing neurons in the hypothalamus (Cowlay et al., 2003). This protein hormone increases plasma glucose concentration, stimulates gastric motility and gastric acid secretion (Du et al., 2007). Moreover, ghrelin has been proposed as a hormone which promotes intestinal cell proliferation and inhibits its apoptosis during inflammatory states and oxidative stress (Waseem et al., 2008). The fact that ghrelin gene is expressed in gilts hypothalamus-pituitary-ovary axis and the levels of ghrelin changed during the oestrous cycle suggests that this protein could play important role in porcine reproduction (Zhang et al., 2008).

Due to various functions of ghrelin, the $G H R L$ gene is considered as a candidate gene responsible for growth and development traits of many species including pigs. In the pig, single polymorphism in third exon has been found so far and according to the authors this mutation is associated with several economically important traits (Kim et al., 2004). The aim of our study was to identify new polymorphisms in the porcine GHRL gene - in exons and in the regulatory regions (promoter region, 5' and 3' untranslated regions). Furthermore, we evaluated GHRL expression in stomach (fundus ventriculis) and ghrelin protein concentration in plasma in three pig breeds: Polish Landrace, Polish Large White and Pietrain. Additionally, we attempted to determined the effect of the newly detected polymorphisms in gene regulatory regions on the level of GHRL mRNA and protein content.

\section{MATERIAL AND METHODS}

\section{Animals}

The animals analysed were maintained in the Pig Test Station of the National Research Institute of Animal Production under the same housing and feeding 
conditions. The parameters measured on individual pigs during the test were: test daily gain (TDG) and daily feed intake (DFI). DFI was electronically recorded for each pig over the test period and was expressed in g/day. TDG was calculated as off-test weight (approx. $100 \mathrm{~kg}$ ) minus on-test weight $(30 \mathrm{~kg}$ ) divided by number of days on test. All animals (female, prepubertal pigs, with an average weight of $100 \mathrm{~kg}$ ) were fasted $48 \mathrm{~h}$ before the slaughter.

The PCR-SSCP analyses were performed on 72 gilts representing 3 pig breeds: Pietrain, Polish Large White (PLW) and Polish Landrace (PL) - 24 sows of each breed. The PCR-RFLP method was carried out on 152 animals (PLW - 48, PL - 66 and Pietrain - 38). The analysis of GHRL gene expression and ghrelin protein level was performed on 62 gilts (PLW - 22, PL - 20 and Pietrain - 20). The expression levels were evaluated in the porcine stomach (fundus ventriculi region). The samples of stomach were collected immediately after slaughter, put in tubes with RNAlater solution (Ambion Inc., Austin, USA) and stored at $-20^{\circ} \mathrm{C}$. The ghrelin protein levels were determined in blood plasma. The blood samples were collected in tubes with EDTA, centrifigued for $15 \mathrm{~min}$, plasma was transferred to fresh tubes and stored at $-20^{\circ} \mathrm{C}$.

\section{PCR-SSCP analysis, DNA sequencing and PCR-RFLP analysis}

DNA was extracted from whole blood samples using the Genomic Wizard Purification Kit (Promega, Madison, WI, USA). To identify new polymorphisms in GHRL gene we used screening PCR-SSCP method. Primers were designed based on sequences accessible in the online genetic database (Ensembl ENSSSCG00000011568 and GeneBank accession no. NM213807.1) using computer programme Primer3 Input (version 0.4.0) (Table 1). An annealing temperature was $55^{\circ} \mathrm{C}$ for all amplified fragments. Five $\mu \mathrm{l}$ of PCR product was mixed with $5 \mu \mathrm{l}$ SSCP denaturing solution $(0.05 \%$ bromophenol blue, $0.05 \%$ xylene cyanol, $95 \%$ formamide). Samples were denaturated for $10 \mathrm{~min}$ at $95^{\circ} \mathrm{C}$ and then renaturated for $5 \mathrm{~min}$ in $4^{\circ} \mathrm{C}$ to obtain individual conformer strands. Electrophoresis was carried out overnight in $10 \%$ polyacrylamide gel (37.5:1 acrylamide to bisacrylamide) in non-denaturing conditions at a constant temperature of $8^{\circ} \mathrm{C}$.

The samples displaying the single strand conformation polymorphisms were sequenced using capillary sequencer CEQ8000 Genetic Analysis System (Beckman Coulter, Brea, CA, USA). Primers used to amplification of the GHRL gene fragments were presented in Table 1. PCR sequencing was performed using GenomeLab DTCS-Quick Start Kit (Beckman Coulter) according to manufacturer's instructions. The results obtained are analysed using $\mathrm{CEQ}^{\mathrm{TM}}$ Genetic Analysis System. 


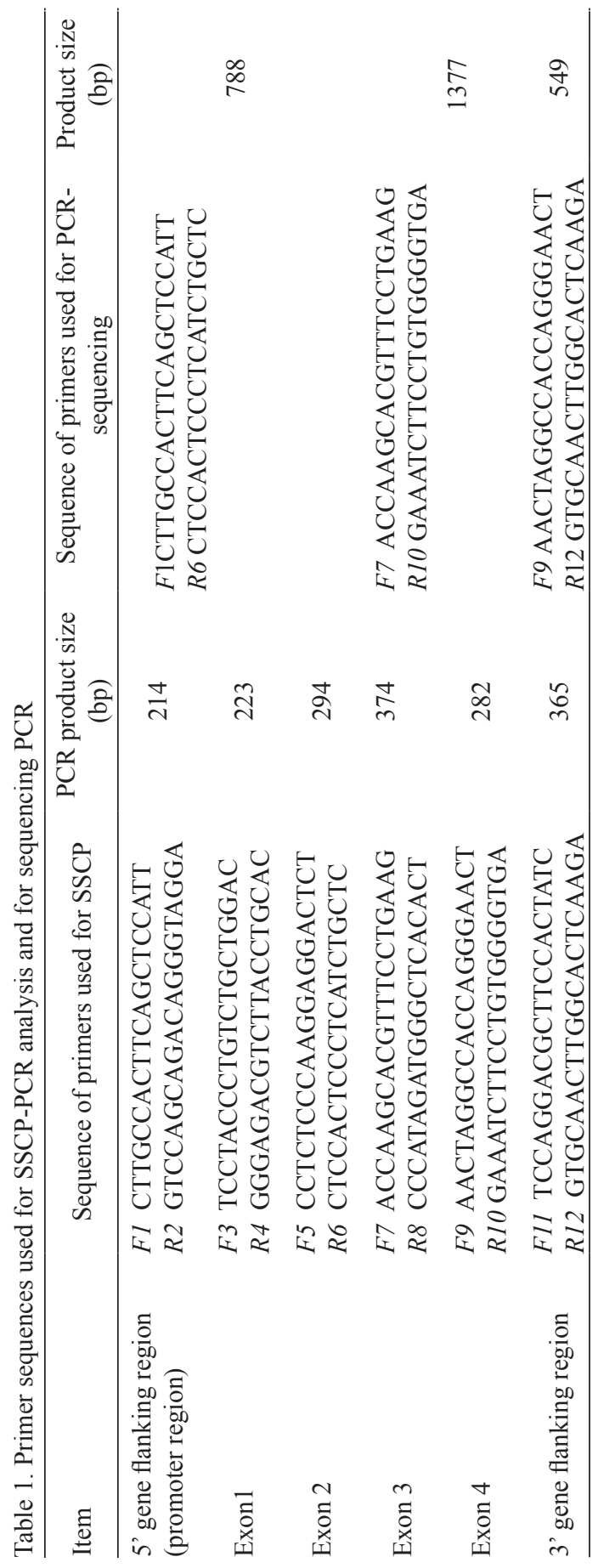


The PCR-RFLP method was used to determine genotype frequencies of five detected polymorphisms (located in regulatory regions and intron 1) in three pig breeds. The restrictions enzymes were selected for detection of individual mutations by using NEBCutter V2.0 (New England BioLabs, Frankfurt, Germany) (Table 2).

Table 2. Novel polymorphisms detected in GHRL gene locus. The PCR-RFLP method was adapted for five single nucleotide polymorphisms

\begin{tabular}{|c|c|c|c|c|}
\hline \multirow{2}{*}{$\begin{array}{l}\text { GHRL gene } \\
\text { fragments }\end{array}$} & \multirow{2}{*}{$\begin{array}{l}\text { Polymorphisms } \\
\text { identified }\end{array}$} & \multicolumn{3}{|c|}{ PCR-RFPLP method } \\
\hline & & $\begin{array}{l}\text { primers (PCR } \\
\text { product size, bp) }\end{array}$ & $\begin{array}{c}\text { restriction } \\
\text { enzyme }\end{array}$ & $\begin{array}{c}\text { length of restriction } \\
\text { products }\end{array}$ \\
\hline \multirow[t]{2}{*}{$\begin{array}{l}\text { ' gene flanking } \\
\text { region }\end{array}$} & & $F 1, R 6(788)$ & MwoI & $\begin{array}{l}\text { A-343,301,109bp } \\
\text { G-301, 195, 148, 109bp }\end{array}$ \\
\hline & c. $-19 \mathrm{C}>\mathrm{T}$ & & & \\
\hline $\begin{array}{l}\text { Exon } 1 \\
\text { (coding region) }\end{array}$ & g. $31 \mathrm{C}>\mathrm{T}$ & $F 3, R 4(223)$ & Sau96I & C-111, 112bp; T-223bp \\
\hline Intron 1 & g. $253 \mathrm{G}>\mathrm{A}$ & $F 1, R 6(788)$ & ApaI & $\begin{array}{l}\text { G-535, 127bp } \\
\text { A-665, 123bp }\end{array}$ \\
\hline Exon 3 & $\begin{array}{l}\text { g. } 3419 \mathrm{G}>\mathrm{A} \\
\text { g. } 3655 \mathrm{G}>\mathrm{T}\end{array}$ & & & \\
\hline Intron 3 & $\begin{array}{l}\text { g. } 4321 \mathrm{G}>\mathrm{T} \\
\text { g. } 4329 \mathrm{~T}>\mathrm{C}\end{array}$ & & & \\
\hline \multirow[b]{2}{*}{ Exon 4 (3'UTR) } & g. $4428 \mathrm{~T}>\mathrm{C}$ & $F 9, R 10(282)$ & $B s l \mathrm{I}$ & T-282bp; C-173, 109bp \\
\hline & g. $4486 \mathrm{C}>\mathrm{T}$ & $F 9, R 10(282)$ & $H g a \mathrm{I}$ & $\begin{array}{l}\text { C-180, 71, 31bp } \\
\text { T-180, 102bp }\end{array}$ \\
\hline
\end{tabular}

the numeration of SNP's is according to the sequence accessible in the online genetic database Ensembl: ENSSSCG00000011568

Reverse transcription and quantitative real-time PCR

The total RNA was isolated using SV Total RNA Isolation System (Promega), according to manufacturer protocol. The quality and quantity of extracted RNA was estimated by using BioPhotometer (Eppendorf, Hamburg, Germany), and 2\% agarose electrophoresis. One $\mu \mathrm{g}$ of total RNA was reverse transcribed into cDNA at $37^{\circ} \mathrm{C}$ using High Capacity cDNA Reverse Transcription Kit with random primers (Applied Biosystems), according to attached protocol. The DNA contamination in RNA samples was checked by real-time PCR with "No-RT" control.

The GHRL mRNA abundance was evaluated on 7500 Real-Time PCR System using labeled TaqMan ${ }^{\circledR}$ probes and TaqMan ${ }^{\circledR}$ Universal PCR Master Mix (Applied Biosystems). The efficiency of real-time PCR reactions was defined by using the standard curve method. Relative quantity of ghrelin mRNA was calculated according to Pfaffl (2001). Three housekeeping genes OAZ1, RPS29 and RPL27, 
previously recommended for gene expression analysis in stomach, were used as an endogenous control (Oczkowicz et al., 2010). Probes were labeled with different dyes and could be tested in one multiplex reaction. Primers and probes for ghrelin $(G H R L)$ and for endogenous controls were described previously (Oczkowicz et al., 2010). Quantitative real-time PCR reaction for each sample (cDNA obtained for individual animal) was performed in three repeats and according to the TaqMan ${ }^{\circledR}$ Universal PCR Master Mix protocol. The results were analysed using Sequence Detection System 7500 software v. 2.0.1 (Applied Biosystems).

\section{Protein measurements (ELISA analyses)}

The concentration of ghrelin in serum was determined by commercially available Porcine Growth Hormone Releasing Peptide-Ghrelin (GHRP-Ghrelin) ELISA Kit (Cusabio Biotech Co., Newark, USA), according to manufacturer's instructions. The ghrelin concentration was evaluated on BioTek Istrument EL808 (Bio-Tek Instruments Inc., Winooski, USA).

\section{Statistical analysis}

The statistical analysis were performed using the ANOVA procedure (SAS Institute, Cary, NC, v. 8.02, 2001). All results were shown as means $\pm \mathrm{SEM}$. Pearson's correlations between the level of GHRL gene expression and protein level were estimated using the COR procedure of SAS software. The haplotype frequencies were estimated with an expectation-maximization algorithm as implemented in the Arlequin 3.11 software. The haplotype analysis was performed in investigated population and pedigree analysis was not considered.

\section{RESULTS}

\section{New polymorphisms, genotype frequencies}

The SSCP-PCR method and DNA sequencing analysis allowed us to identify ten single nucleotide polymorphisms (Table 2). Four SNP's were located in exons: substitution g. $31 \mathrm{C}>\mathrm{T}$ in exon 1, silent mutation g. $3419 \mathrm{G}>\mathrm{A}$ in the third exon and two substitution (g.4428T $>$ C, g.4486C $>$ T) in 3'UTR. Furthermore, two detected polymorphisms were localized in promoter region (c.-93A $>$ G identified by $M w o I$ and c. $-19 A>G)$. The identified mutations were reported to the Single Nucleotide Polymorphism Database (dbSNP NCBI) and received SNP ID numbers: c. $-93 \mathrm{~A}>\mathrm{G}$ - ss\#410758761; g.31C > T - ss\#410758762; g.253G >A - ss\#410758763; g.4428T >C - ss \#410758764; g.4486C >T - ss\#410758765. 
We estimated genotype frequencies for polymorphisms located in regulatory regions, exon 1 and intron 1 by PCR-RFLP method. A total 152 gilts from three investigated breeds was determined for each polymorphism (Table 3). Genotypes frequency for polymorphism c. $-19 \mathrm{~A}>\mathrm{G}$ located in promoter region was not established, because no specific restriction sites were generated. The g.253G $>$ A mutation identified by endonuclease ApaI occurred in all analysed breeds.

Table 3. The genotype frequencies of selected polymorphisms in GHRL gene in 3 breeds of pigs

\begin{tabular}{|c|c|c|c|c|c|c|}
\hline \multirow{3}{*}{ Breed } & \multicolumn{6}{|c|}{ c. $-93 \mathrm{~A}>\mathrm{G}(M w o \mathrm{I})$} \\
\hline & & $\mathrm{n}$ & & $\mathrm{n}$ & & $\mathrm{n}$ \\
\hline & \multicolumn{2}{|c|}{ AA } & \multicolumn{2}{|c|}{$\mathrm{AG}$} & \multicolumn{2}{|c|}{ GG } \\
\hline PLW & 0.56 & (27) & 0.44 & (21) & - & - \\
\hline PL & 0.74 & (49) & 0.26 & (17) & - & - \\
\hline Pietrain & 1 & (38) & - & - & - & - \\
\hline Total & 0.75 & (114) & 0.25 & (38) & & \\
\hline
\end{tabular}

\begin{tabular}{lccccccc} 
& \multicolumn{8}{c}{ g.31C $>$ T $($ Sau96) } \\
\cline { 2 - 8 } & \multicolumn{9}{c}{ CC } & \multicolumn{3}{c}{ CT } & \multicolumn{3}{c}{ TT } \\
\hline PLW & 0.54 & & $(26)$ & 0.40 & $(19)$ & 0.06 & $(3)$ \\
PL & 0.68 & $(45)$ & 0.287 & $(19)$ & 0.03 & $(2)$ \\
Pietrain & 1 & & $(38)$ & - & - & - & -
\end{tabular}

Total $\quad 0.72 \quad(109) \quad 0.25 \quad$ (38)

\begin{tabular}{|c|c|c|c|c|c|c|}
\hline \multirow{3}{*}{$\overline{\text { PLW }}$} & \multicolumn{6}{|c|}{ g. $253 \mathrm{G}>\mathrm{A}($ ApaI $)$} \\
\hline & \multicolumn{2}{|c|}{ GG } & \multicolumn{2}{|c|}{ GA } & \multicolumn{2}{|c|}{ AA } \\
\hline & 0.08 & (4) & 0.46 & (22) & 0.46 & (22) \\
\hline PL & 0.12 & (8) & 0.53 & (35) & 0.35 & (23) \\
\hline Pietrain & - & - & 0.13 & (5) & 0.87 & (33) \\
\hline \multirow[t]{3}{*}{ Total } & 0.08 & (12) & 0.41 & $(62)$ & 0.51 & (78) \\
\hline & \multicolumn{6}{|c|}{ g. $4428 \mathrm{~T}>\mathrm{C}(B s l \mathrm{I})$} \\
\hline & \multicolumn{2}{|c|}{ TT } & \multicolumn{2}{|c|}{$\mathrm{TC}$} & \multicolumn{2}{|c|}{$\mathrm{CC}$} \\
\hline$\overline{\text { PLW }}$ & 0.895 & (43) & 0.083 & (4) & 0.022 & (1) \\
\hline PL & 0.07 & $(5)$ & 0.34 & (22) & 0.59 & (39) \\
\hline Pietrain & - & - & 0.13 & $(5)$ & 0.87 & (33) \\
\hline \multirow[t]{3}{*}{ Total } & 0.32 & (48) & 0.20 & (31) & 0.48 & (73) \\
\hline & \multicolumn{6}{|c|}{ g. $4486 \mathrm{C}>\mathrm{T}(H g a I)$} \\
\hline & \multicolumn{2}{|c|}{$\mathrm{CC}$} & \multicolumn{2}{|c|}{$\mathrm{CT}$} & \multicolumn{2}{|c|}{ TT } \\
\hline PLW & - & - & 0.15 & (7) & 0.85 & (41) \\
\hline PL & 0.045 & (3) & 0.32 & (21) & 0.635 & (42) \\
\hline Pietrain & - & - & 0.13 & (5) & 0.87 & (33) \\
\hline Total & 0.02 & (3) & 0.22 & (33) & 0.76 & (116) \\
\hline
\end{tabular}

PLW - Polish Large White, PL - Polish Landrace 
Allele A was predominant, and the GG genotype was observed only in PLW and PL breeds. On the other hand, for g.4428T $>$ C (BslI) polymorphism, wild type allele $\mathrm{T}$ (according to reference sequence Ensembl ENSSSCG00000011568) was predominant in PLW and contrariwise allele $\mathrm{C}$ was more frequent in PL and Pietrain breed. Interestingly, in Pietrain pigs we did not observe both c.-19A $>$ G (MwoI) and g.31C $>\mathrm{T}$ (Sau96I) mutations, thus all animal presented the wild type genotype. In the case of substitution g.4486C $>\mathrm{T}(\mathrm{HgaI})$ allele $\mathrm{T}$ was predominant, TT genotype have high frequency when compared to $\mathrm{CC}$ genotype in all analysed breeds.

Furthermore, we preformed haplotype analysis in GHRL locus which included all five investigated polymorphism. According to Arlequin software the total number of possible haplotypes was 32 and sum of all haplotype frequencis was 1.000. Table 4 showed 19 most frequent haplotypes (frequencies above 0.001 ), and one of them had high frequency - AATCC - 0.506. The g.31C $>$ T and g.253G $>$ A polymorphism were found to be in linkage disequilibrium (LD) $(\mathrm{P}<0.05)$.

Table 4. The 19 most frequent five-locus haplotypes in GHRL gene $(\mathrm{n}=152)$

\begin{tabular}{rrrrrrrl}
\hline & \multicolumn{5}{c}{ Haplotypes } & & \multirow{2}{*}{ Frequencies } \\
\cline { 2 - 5 } & g. $253 \mathrm{G}>\mathrm{A}$ & c. $-93 \mathrm{~A}>\mathrm{G}$ & g.4486C $>$ T & g.4428T $>$ C & g.31C $>$ T & \\
\hline 1 & $\mathrm{~A}$ & $\mathrm{~A}$ & $\mathrm{~T}$ & $\mathrm{C}$ & $\mathrm{C}$ & 0.506 \\
2 & $\mathrm{G}$ & $\mathrm{A}$ & $\mathrm{T}$ & $\mathrm{T}$ & $\mathrm{C}$ & 0.079 \\
3 & $\mathrm{~A}$ & $\mathrm{~A}$ & $\mathrm{C}$ & $\mathrm{C}$ & $\mathrm{C}$ & 0.064 \\
4 & $\mathrm{G}$ & $\mathrm{G}$ & $\mathrm{T}$ & $\mathrm{C}$ & $\mathrm{T}$ & 0.054 \\
5 & $\mathrm{G}$ & $\mathrm{A}$ & $\mathrm{T}$ & $\mathrm{C}$ & $\mathrm{C}$ & 0.049 \\
6 & $\mathrm{~A}$ & $\mathrm{~A}$ & $\mathrm{~T}$ & $\mathrm{C}$ & $\mathrm{T}$ & 0.043 \\
7 & $\mathrm{G}$ & $\mathrm{G}$ & $\mathrm{T}$ & $\mathrm{C}$ & $\mathrm{C}$ & 0.028 \\
8 & $\mathrm{G}$ & $\mathrm{A}$ & $\mathrm{T}$ & $\mathrm{C}$ & $\mathrm{T}$ & 0.023 \\
9 & $\mathrm{~A}$ & $\mathrm{~A}$ & $\mathrm{~T}$ & $\mathrm{~T}$ & $\mathrm{C}$ & 0.015 \\
10 & $\mathrm{G}$ & $\mathrm{G}$ & $\mathrm{C}$ & $\mathrm{C}$ & $\mathrm{C}$ & 0.014 \\
11 & $\mathrm{G}$ & $\mathrm{A}$ & $\mathrm{C}$ & $\mathrm{T}$ & $\mathrm{C}$ & 0.012 \\
12 & $\mathrm{~A}$ & $\mathrm{G}$ & $\mathrm{T}$ & $\mathrm{C}$ & $\mathrm{C}$ & 0.008 \\
13 & $\mathrm{~A}$ & $\mathrm{~A}$ & $\mathrm{C}$ & $\mathrm{C}$ & $\mathrm{T}$ & 0.007 \\
14 & $\mathrm{~A}$ & $\mathrm{G}$ & $\mathrm{T}$ & $\mathrm{T}$ & $\mathrm{C}$ & 0.0066 \\
15 & $\mathrm{G}$ & $\mathrm{A}$ & $\mathrm{T}$ & $\mathrm{T}$ & $\mathrm{T}$ & 0.0065 \\
16 & $\mathrm{G}$ & $\mathrm{A}$ & $\mathrm{C}$ & $\mathrm{C}$ & $\mathrm{C}$ & 0.006 \\
17 & $\mathrm{G}$ & $\mathrm{G}$ & $\mathrm{C}$ & $\mathrm{C}$ & $\mathrm{T}$ & 0.0046 \\
18 & $\mathrm{~A}$ & $\mathrm{G}$ & $\mathrm{T}$ & $\mathrm{C}$ & $\mathrm{T}$ & 0.0034 \\
19 & $\mathrm{G}$ & $\mathrm{G}$ & $\mathrm{T}$ & $\mathrm{T}$ & $\mathrm{T}$ & 0.001 \\
\hline
\end{tabular}

Expression of GHRL gene in fundus ventriculi

The results showed that transcript abundance of GHRL gene in fundus ventriculi was significantly higher $(\mathrm{P}<0.05)$ in Polish Landrace than in Pietrain and Polish Large White breeds (Figure 1). Furthermore, we determined 


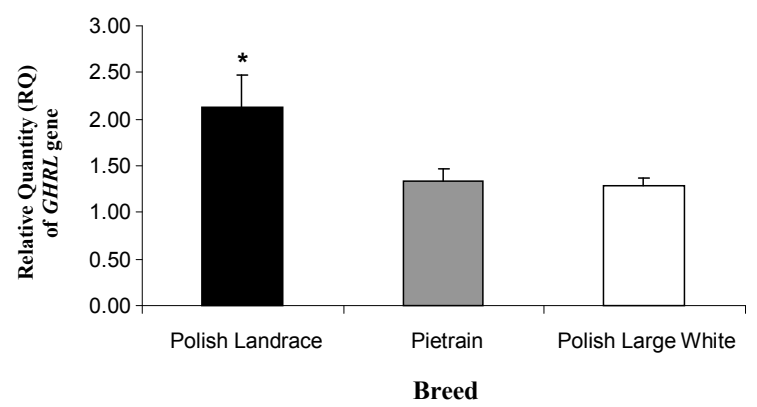

Figure 1. Statistically significant difference between Relative quantity (RQ) of GHRL transcript in stomach (fundus ventriculis) in three pig breeds (Polish Landrace - 20, Pietrain - 20 and Polish Large White $-22, * \mathrm{P}<0.05)$. Data are means $\pm \mathrm{SEM}$

the effect of the polymorphisms in regulatory regions on the expression level of ghrelin. The substitution c.-93A $>$ Glocated in promoter region affected the transcript abundance of GHRL gene. The animal with AA $(\mathrm{n}=49)$ genotype showed a significantly $(\mathrm{P}<0.05)$ higher expression level of this gene when compared to AG ( $n=13)$ genotype animals (Figure 2). Regarding this polymorphism, there were no GG animals in any investigated breeds. For this reason, this aspect will be examined in greater detail in a future research. Because c. $-93 \mathrm{~A}>\mathrm{G}$ polymorphism located in promoter region affected mRNA abundance of GHRL gene, we performed bioinformatics analysis of transcription factors binding sites (TESS - Transcription Element Search System). The analysis showed that detected mutation eliminates binding sites for REB1 transcription factor and generates a new binding site for Ttk69k, Ttk, T3R-alpha and Sp-1 transcription factors. These observation should be proven in further research by using experimental EMSA method.

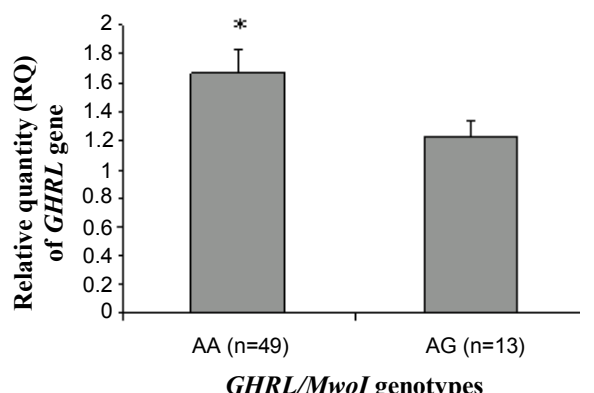

Figure 2. Relative quantity (RQ) of the mRNA abundance of different $G H R L / M w o I(c .-93 \mathrm{~A}>\mathrm{G})$ genotypes $(* \mathrm{P}<0.05)$. Data are means $\pm \mathrm{SEM}$ 


\section{Ghrelin (GHRP) protein concentration in plasma}

Our results showed that ghrelin concentration in plasma was $50.01 \pm 0.62 \mathrm{pg} /$ $\mathrm{ml}$. There was no significant difference of plasma ghrelin levels between three investigated breeds (Polish Landrace - 49.71 $\pm 0.79 \mathrm{pg} / \mathrm{ml}$, Pietrain - 50.17 \pm 0.60 $\mathrm{pg} / \mathrm{ml}$ and Polish Large White $-50.66 \pm 1.50 \mathrm{pg} / \mathrm{ml}$ ). We also determined the effect of the c. $-93 \mathrm{~A}>\mathrm{G}$, g. $31 \mathrm{C}>\mathrm{T}, \mathrm{g} .235 \mathrm{G}>\mathrm{A}, \mathrm{g} .4428 \mathrm{~T}>\mathrm{C}$, g.4486C $>\mathrm{T}$ polymorphisms on the GHRP protein level. The analysis showed that these mutations did not significantly effect on ghrelin concentrations in plasma. Moreover, we did not observed significant correlation $\left(\mathrm{r}^{2}=0.22 ; \mathrm{P}<0.10\right)$ between $G H R L$ mRNA expression levels and protein contents.

\section{DISCUSSION}

The amino acid sequences of ghrelin hormones in mammals, particularly acyl-modification regions, are highly conserved (Kojima et al., 2008). Porcine ghrelin is a 28 -amino acid peptide which has two major endogenous forms: desacylated (des-acyl ghrelin) and acylated at third serine (ghrelin). In the pig, GHRL gene consists of four exons coding for ghrelin precursors which are synthesized as a 118-residue prepro-peptide (Dong et al., 2009). In order to determine new polymorphisms, we analysed several fragments of GHRL gene included coding sequences (four exons), introns (1, 3), 5' and 3' flanking regions. We identified ten single nucleotide polymorphisms from which three were located in 5' or 3'UTR regions and two in promoter region. In previous study of human ghrelin, the affinity of transcription factors to promoter region was investigated and some specific transcription factors which domains bind to this region were identified (Kishimoto et al., 2003). Polymorphisms in these sites might regulate the GHRL gene expression, because 5' and 3'UTR regions have a principal role in controlling gene expression by regulating stability, polyadenylation and localization of mRNA, and by regulating translation.

Until now, the knowledge about polymorphisms in porcine ghrelin gene, their association with expression and protein levels or ghrelin function is very poor. Kim et al. (2004) found single polymorphism in the third exon of porcine GHRL gene, which was correlated with a several porcine traits, such as marbling, backfat thickness and weights of loin and ham. Jin et al. (2010) investigated several polymorphisms in caprine ghrelin gene and they confirmed association between mutation in second intron (G147A) and growth traits such as: circumference of chest and cannon, and also trunk index $(\mathrm{P}<0.05$ and $\mathrm{P}<0.01)$. The authors observed tendency that genotype AG had better performance in body height and body length 
than genotype GG, although no significant differences were observed. In chickens and ducks, the several polymorphisms were found in GHRL gene and some of them were scientifically associated with abdominal fat weight, crude protein content of leg muscle and subcutaneous fat thickness (Nie et al., 2009). Sherman et al. (2008) identified in cattle GHRL gene, polymorphism in the third intron but it showed minor associations with the feed efficiency traits.

Moreover in the human, numerous researches about association between polymorphisms in GHRL gene and obesity have been carried out. However, the obtained results indicate that polymorphisms in ghrelin and alike in its receptor genes do not exert a major influence on the development of obesity, which is a polygenic trait, although some of variants may alter body weight, eating behaviour and contribute to insulin resistance, in particular in early obesity (Gueorguiev et al., 2009).

Previous studies informed that the highest expression of GHRL gene is observed in stomach. However in pig, ghrelin mRNA was also detected in hypothalamus, liver, kidney, heart, pancreas, ileum, jejunum and duodenum (Yang et al., 2004). In the rodent, GHRL transcript was observed in pituitary, testis and ovary (Caminos et al., 2003). Zhang et al. (2008) showed that expression of ghrelin mRNA in the hypothalamus, pituitary, ovary and stomach depended on the phases of oestrous cycle. However, the most important factor which regulates the expression and release of ghrelin is feed intake (fasted or fed). Starvation increases ghrelin expression in the gastric fundus and ghrelin peptide content in blood (Salfen et al., 2004). Some reports showed that in pig, nutrient content of the diet regulates ghrelin expression at the post-transcriptional level (Zhang et al., 2007; Yin et al., 2009). Both transcript abundance of GHRL gene and peptide plasma concentrations are related with feeding behaviour in pig. Therefore in our study, we estimated GHRL gene expression in porcine stomach - fundus ventriculi - in three breeds differing in muscularity and the fat content. In previous research (Oczkowicz et al., 2010) we evaluated mRNA abundance in two regions of stomach using several endogenous reference genes. The ghrelin gene was highly expressed in both regions of stomach, however, level of GHRL mRNA was approximately 6-fold higher in fundus ventriculi than in diverticulum ventriculi. The ghrelin expression levels is strongly related with feed intake. All animals were fasted $48 \mathrm{~h}$ before the slaughter to exclude influence of the degree of filling the stomach on grelin level. In present study, the results showed that expression level of GHRL gene in fundus ventriculi was significantly higher in Polish Landrace than in Pietrain and Polish Large White breeds $(\mathrm{P}<0.05)$.

The comparison of the growth performance traits such as daily feed intake ( $\mathrm{kg} /$ day) and test daily gain (g/day) between breeds showed the highest average daily gain PL (2.49 kg/day) and PLW (2.45 kg/day) pigs and these breeds do not 
differ significantly in daily gain. On the other hand, the Pietrain animals had the lowest DFI (2.35 kg/day) and TDG ( $823 \mathrm{~g} /$ day). The differences in transcript level between breeds which have similar growth rate (PLW and PL pigs) might be the result of different genetic origin of these breeds. The reason for these differences in GHRL transcript abundance could be explain by existence of polymorphisms specific for breeds which have not been identified so far.

In the present study we defined correlation between new polymorphisms, GHRL transcript abundance and ghrelin concentration in plasma. The ghrelin protein level was about $50 \mathrm{pg} / \mathrm{ml}$ and it was accordance with literature data (Salfen et al., 2004). Our results showed that polymorphism located in promoter region (c.-93A $>$ G) affected expression level of GHRL gene. However, there was no significant relationship between mRNA levels and protein concentrations. Similarly, we observed statistically significant differences in GHRL transcript abundance, but not in protein levels, between investigated breeds. The results obtained might suggest that ghrelin protein level is mainly controled by regulation of posttranscriptional modifications or translation process. Yin et al. (2009) indicated that dietary supplementation with zinc oxide enhanced ghrelin production from gastric mucosal cells without affecting ghrelin mRNA levels. This research confirmed post-transcriptional regulation of ghrelin secretion from the stomach.

\section{CONCLUSIONS}

In present research new polimorphic sites in GHRL gene was identifed, estimated transcript abundance in stomach and protein content in plasma. We observed a significant impact of (c.-93A $>\mathrm{G})$ polymorphism on the mRNA abundance, however the effect was not observed at the protein level. This results suggested that ghrelin level is regulated by post-transcriptional modification. In the future, it is necessary to define the relationship between single nucleotide polymorphisms in GHRL locus and growth traits in pigs.

\section{REFERENCES}

Caminos J.E., Tena-Sempere M., Gaytan F., Sanchez-Criado J.E., Barreiro M.L., Nogueiras R., Casanueva F.F., Aguilar E., Diéguez C., 2003. Expression of ghrelin in the cyclic and pregnant rat ovary. Endocrinology 144, 1594-1602

Chen C.Y., Chao Y., Chang F.Y., Chien E.J., Lee S.D., Doong M.L., 2005. Intracisternal des-acyl ghrelin inhibits food intake and non-nutrient gastric emptying in conscious rats. Int. J. Mol. Med. 16, 695-699

Cowley M.A., Smith R.G., Diano S., et al., 2003. The distribution and mechanism of action of ghrelin in the CNS demonstrates a novel hypothalamic circuit regulating energy homeostasis. Neuron 37, 649-661 
Dong X.-Y., Xu J., Tang S.-Q., Li H.-Y., Jiang Q.-Y., Zou X.-T., 2009. Ghrelin and its biological effects on pigs. Peptides 30, 1203-1211

Du G.M., Shi Z.M., Wei X.H., Liu M.J., Zhang L., Zhao R.Q., 2007. Expression of gastric ghrelin and $\mathrm{H}(+)-\mathrm{K}(+)$-ATPase mRNA in weanling piglets and effect of ghrelin on $\mathrm{H}(+)-\mathrm{K}(+)$-ATPase expression and activity in gastric mucosal cells in vitro. Res. Vet. Sci. 82, 99-104

Glavaski-Joksimovic A., Jeftinija K., Scanes C.G., Anderson L.L., Jeftinija S., 2003. Stimulatory effect of ghrelin on isolated porcine somatotropes. Neuroendocrinology 77, 367-379

Gueorguiev M., Lecoeur C., Meyre D., et. al., 2009. Association studies on ghrelin and ghrelin receptor gene polymorphisms with obesity. Obesity $17,745-754$

Jin Q.J., Fang X.T., Zhang C.L., et al., 2010. A novel SNP of the GHRL gene in goat and its association with growth traits. Small Ruminant Res. 90, 150-152

Kim K.S., Thomsen H., Bastiaansen J., Nguyen N.T., Dekkers J.C., Plastow G.S., Rothschild M.F., 2004. Investigation of obesity candidate genes on porcine fat deposition quantitative trait loci regions. Obes. Res. 12, 1981-1994

Kishimoto M., Okimura Y., Nakata H., Kudo T., Iguchi G., Takahashi Y., Kaji H., Chihara K., 2003. Cloning and characterization of the 5-flanking region of the human ghrelin gene. Biochem. Biophys. Res. Commun. 305, 186-192

Kojima M., Hosoda H., Date Y., Nakazato M., Matsuo H., Kangawa K., 1999. Ghrelin is a growthhormone-releasing acylated peptide from stomach. Nature 402, 656-660

Kojima M., Ida T., Sato T., 2008. Structure of mammalian and nonmammalian ghrelins. Vitam. Horm. 77, 31-46

Kokkinos A., Mourouzis I., Kyriaki D., Pantos C., Katsilambros N., Cokkino D.V., 2007. Possible implications of leptin, adiponectin and ghrelin in the regulation of energy homeostasis by thyroid hormone. Endocrine 32, 30-32

Leite-Moreira A.F., Rocha-Sousa A., Henriques-Coelho T., 2007. Cardiac, skeletal, andsmooth muscle regulation by ghrelin. Vitam. Horm. 77, 207-238

Nakazato M., Murakami N., Date Y., Kojima M., Matsuo H., Kangawa K., Matsukura S., 2001. A role for ghrelin in the central regulation of feeding. Nature 409, 194-198

Nie Q., Fang M., Xie L., Peng X., Xu H., Luo C., Zhang D., Zhang X., 2009. Molecular characterization of the ghrelin and ghrelin receptor genes and effects on fat deposition in chicken and duck. J. Biomed. Biotechnol. ID 567120, 1-12

Oczkowicz M., Różycki M., Piórkowska K., Piestrzyńska-Kajtoch A., Rejduch B., 2010. A new set of endogenous reference genes for gene expression studies of porcine stomach. J. Agr. Food Sci. 19, 611-617

Salfen B.E., Carroll J.A., Keisler D.H., Strauch, T.A., 2004. Effects of exogenous ghrelin on feed intake, weight gain, behavior, and endocrine responses in weanling pigs. Amer. J. Sci. 82, 19571966

Sherman E.L., Nkrumah J.D., Murdoch B.M., Li C., Wang Z., Fu A., Moore S.S., 2008. Polymorphisms and haplotypes in the bovine neuropeptide Y, growth hormone receptor, ghrelin, insulin-like growth factor 2, and uncoupling proteins 2 and 3 genes and their associations with measures of growth, performance, feed efficiency, and carcass merit in beef cattle. Amer. J. Sci. $86,1-16$

Toshinai K., Yamaguchi H., Sun Y., et al., 2006. Des-acyl ghrelin induces food intake by a mechanism independent of the growth hormone secretagogue receptor. Endocrinology 147, 2306-2314

Waseem T., Duxbury M., Ito H., Ashley S.W., Robinson M.K., 2008. Exogenous ghrelin modulates release of pro-inflammatory and anti-inflammatory cytokines in LPS-stimulated macrophages through distinct signaling pathways. Surgery 143, 334-342

Yang L.Y., Yang W.Y., Ji F.J., Zhao Y.C., Jia R., Wang Z., 2004. Study on gene cloning and mRNA distribution of pig ghrelin. J. Jilin Agr. Univ. 26, 86-88 
Yin J., Li X., Li D., Yue T., Fang Q., Ni J., Zhou X., Wu G., 2009. Dietary supplementation with zinc oxide stimulates ghrelin secretion from the stomach of young pigs. J. Nutr. Biochem. 20, 783-790

Zhang H.W., Yin J.D., Li D.F., Zhou X., Li X., 2007. Tryptophan enhances ghrelin expression and secretion associated with increased food intake and weight gain in weanling pigs. Domest. Anim. Endocrinol. 33, 47-61

Zhang W., Lei Z., Su J., Chen S., 2008. Expression of ghrelin in the porcine hypothalamo- pituitaryovary axis during the estrous cycle. Anim. Reprod. Sci. 109, 356-367 